\title{
ACRL addresses the fulure,
}

\section{part 1}

\section{ACRL's 8 th National Conference soared to new beights}

E xcitement, enthusiasm, and intellectual stimulation permeated the discussions as 2,973 participants explored the theme "Choosing Our Futures" at ACRL's 8th National Conference in Nashville, April 11-14, 1997.

Nearly 1,900 librarians representing all 50 states and nine foreign countries participated in the more than 226 sessions which included a keynote presentation, five invited papers, 42 contributed papers, 38 panel sessions, 100 roundtable discussions, and 40 poster sessions. More than 150 companies brought 756 exhibitors and 190 individuals used ACRL's free exhibits passes to examine state-of-the-art products and services available to academic libraries.

Not only were the numbers of attendees the highest since 1989 , the attendees were also very enthusiastic about their participation:

"This was one of the best conferences I've ever attended."

"On our limited travel budget this conference is the best for the money."

"Very relevant."

"The ACRL conference was exactly the kind of conference l've been looking for-devoted to academic library issues, practical information from excellent presenters, well organized."

"This conference had a number of interesting and challenging sessions that allows me to take back to my campus certain information that can be used to implement various projects."

Librarians had the opportunity to engage academic administrators in useful conversation about the future of libraries in relation to changing campus missions. Alan Guskin, chancellor of Antioch University, explored how universities will need to be restructured to focus on student learning. Eli Noam, professor of busi- ness and finance at Columbia University, posited that libraries will be weakened by the growing communication technologies. ACRL made use of these electronic communication methods by mounting both of these papers and other information about the conference on its Web site.

Participants also had the opportunity to take home plenty of practical ideas for managing their libraries' services and collections. The recent addition of roundtables to the conference program continued to be a popular way to network and share ideas informally with colleagues, drawing more than 400 individuals to each of the sessions.

Conference attendees made time for fun too, and packed the dance floor of the Wild Horse Saloon at the All-Conference Reception. From country line dancing to the hits of the 60 s and 70 s, the music and the party were a great way to celebrate this successful conference.

CERL News is pleased to offer the following summaries of some conference programs and thanks the many volunteers who provided these reports. Part two will appear in the July/August issue. If you want more details about the sessions, many were audiotaped (see the insert in this issue for a list of available tapes) and the contributed papers will be mounted on ACRL's Web page.-Mary Ellen Davis

\section{Cornel West calls for courage}

The always eloquent Dr. Cornel West, professor of philosophy of religion and Afro-American studies at Harvard University, set the tone for ACRL's 8th National Conference with a passionate and provocative keynote address, "Race Matters." West's lecture was not, however, a mere rehashing of the ideas contained in his 1993 bestselling collection of essays of the same name. Rather West's speech was a rousing call to boldly face the twin problems of poverty and paranoia that threaten our democracy. 
West began by paying tribute to libraries and librarians, noting that "libraries changed my life" and adding that the bookmobile gave him "access to a very different world" and allowed him to develop "something profoundly un-American, a sense of history."

West then critiqued the tendency of some Americans to prefer "hollow, shallow, shadowless" world views. Calling color blindness proof of "the limitation of the American imagination," West mocked those Republicans who claimed they never noticed General Colin Powell was black. "Why did you have to eliminate his body," West quipped, "to see him?"

There is a serious message behind West's witticism. These superficial thinkers, according to West, "reluctant to deal with the darkness and thunder" in the world, are ill prepared for a future that includes "escalating levels of despair" among the poor and "escalating levels of distrust" among the affluent. Both are factors that enclanger our democracy. As West observed darkly, "Democracies tend to be short-lived."

West then ended his address by listing four things we can do to "leave the world a little better than we found it": 1) "begin a serious confrontation with history"; 2) avoid becoming "idolatrous about market values"; 3) accent courage because the chief question of the future is "Will we have enough courage?" and 4) but realize "it takes tremendous courage to love."-Jack Helbig, ACRL

\section{Yes, you can perform outcomes assessment on instruction efforts}

In "A Method of Measuring the Reach of a Bibliographic Instruction Program," Sara Penhale reported on a new method devised at Earlham College using readily available data to measure the reach of their extensive program of instruction across the curriculum. Student transcript data (which students took what courses) are merged with instruction statistics (for which courses instruction was done) and with data from a survey of faculty as to which of their courses required library research without scheduled instruction. This quantitative analysis yields results which can then be used to write library instruction program objectives relating to its frequency in a student's curriculum, its consistency with information needs, and its availability in all disciplines.

In "Assessment of Information Literacy Programs: Lessons from the Higher Education Assessment Movement," drawing from Trudy

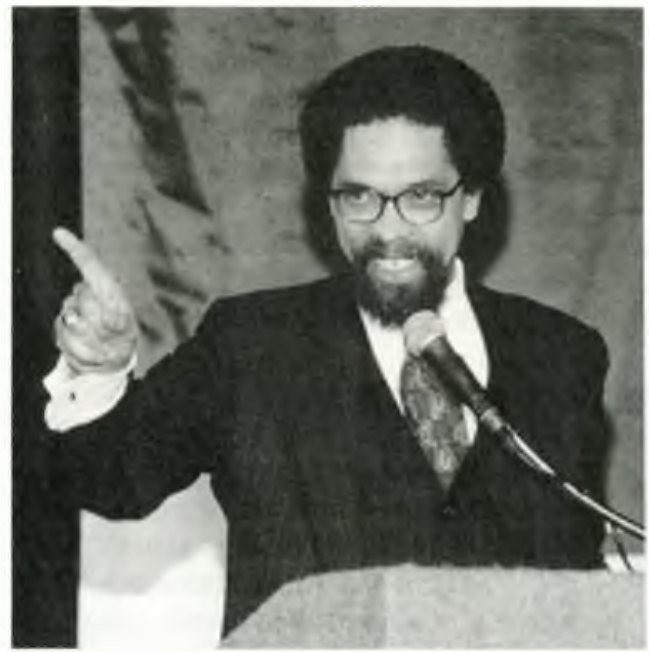

Cornel West challenged listeners to leave the world "a little better than we found it."

Banta et al.'s Assessment in Practice, Mary Pagliero Popp (Indiana University) described effective outcomes assessment as beginning with stated goals and objectives, reflecting learning as multidimensional over time, considering both outcomes and the experiences which lead to them, and being student-centered. Methods include formal tests, performance appraisal, selfreport, behavioral observation, portfolios of work, classroom assessment, focus groups, satisfaction surveys, learning logs, and capstone seminars. For one-shot library instruction sessions, assessment may be as simple as the oneminute paper describing the most important concept presented, the one-sentence summary of what was learned, or the statement of the least clear point.-Anne Berwind, Austin Peay State University

\section{HBCUs' virtual archives; diverse workforce in libraries}

In "Policies and Issues Related to African American Archives, Electronic Information and Diversity: An Urgent Agenda," panelists Itibari M. Zulu and Ann A. Shockley discussed digitizing African American archives. They envision the world having access to historically black colleges' and universities' (HBCU) archives via the Web. Zulu spoke of a need for an association or clearinghouse that will decide what archives at HBCUs should be accessible via the Web. Shockley shared her thoughts about considerations for digitizing HIBCU's archival manuscript collections. Organized archival collections, support from college presidents, and digitizing 
project funds from corporations are considerations. Cultural diversity was another topic discussed. Moderator V. Perry-Evans introduced the third panelist, E. J. Josey, as a pioneer in black librarianship. Josey believes there are miles to go before diversity is achieved in academic libraries and a team approach is one way of developing that diversity,-Nancy Allen, University of South Florida at Sarasota

\section{E-journals: Are we there yet?}

In "Academic Use of Electronic Publications in Social Sciences and Humanities and Changing Roles for Libraries," Linda McCann described the results of a study she conducted at the University of Southern California during academic year 1995/96 which probed faculty attitudes towards the impact of electronic publishing on their research.

Although the faculty in this study recognized the importance of electronic publishing, most did not understand what it really was, especially with regard to the Internet. Most worried about the lack of peer review, suggesting that until a core of prestigious journals was available online and copyright issues were resolved, many would not participate. Lack of appropriate equipment and problems with printing or downloading articles were further barriers to active involvement. As McCann noted, "they recognized an inevitability about [electronic publishing] and hoped it would be different when they had to participate."

In "The Nature of the Electronic Journal: Structure and Use of Information in Scholarly Electronic Journals," Barbara DeFelice described a Web journals test conducted at Dartmouth College, in which $108 \mathrm{Web}$ documents were made available to the campus through the online cata$\log$.

Comments about the project suggest that, although many professors liked the idea of having access to electronic journals, the bot- tom line was to get a quality print quickly. Whether this occurred more successfully in electronic or print format depended on individual definitions of availability and convenience. In fact, some professors were overwhelmed by the amount of material on the Web. DeFelice noted that "they don't want more that is harder to get."

Feeclback from this project suggests that librarians will have to take a more active role in connecting users with relevant electronic journals, informing them about the varied features at each site, and teaching them how to access, search, and manipulate data at these sites.Barbara Valentine, Linfield College

\section{Changing roles, new relationships for libraries and vendors}

Although the speakers at "Libraries and Vendors/Libraries As Vendors: How New Methods of Publication Create New Partnerships and New Competitors" did not claim to have solutions to the "serials crisis," each offered perspectives on library and vendor adaptations, Ilene Rockman (California Polytechnic State University) outlined publication methods that blur the line between in formation producers and consumers, including Project Muse and JSTOR. Such projects necessitate creative partnerships, strategic alliances, and "valueadded" collaborations.

Eve Davis detailed EBSCO's partnerships with research universities like the University of California-Berkeley to form the EBSCOdoc document-delivery service. Davis reinforced the need for open communication between libraries and vendors and encouraged libraries to make vendors "part of the team."

Linda Dobb (Bowling Green State University) compared the serials crisis with the Vietnam War; libraries thought they were right to become information producers partnering with vendors, yet libraries are now vendor competitors, and may be enmeshed in uncomfortable partnerships. 
Libraries should not purchase products if they necessitate constant changes in workflow and services. Dobbs urged librarians to proactively drive user interfaces, choose information products, improve the Internet, and include disenfranchised groups. She does not want libraries becoming outmoded like bank buildings, asserting libraries must "change or die."April Purcell. Austin Peay State University

\section{Will universities survive?}

Eli Noam (Columbia Institute for Teleinformation, Columbia University) threw down the gauntlet in his session called "Electronics and the Future of the University" by predicting decades of strife for the university as it faces the challenges of the information age. The traditional university is based upon place because students and scholars needed to come to the university's information storehouse, the library, for this scarce commodity. This is changing as information technology fosters remote access to information. In addition, the traditional university is very expensive. Less expensive alternatives, according to Noam, are interlinked information communities of scholars, ready access to information without the library as go-between, and the emergence of other nonprofit and commercial teaching services. Even worse, he did not believe that the university is capable of self-reform.

The three panel members each took exception to Noam's conclusions based upon economic factors. Rebecca Martin (University of Vermont) contended that he overestimated the impact of technology in the short term. The historical precedent provides many examples of successful resistance to radical change. The university and the library will use this breathing room to adapt successfully to the new environment for teaching and research. Richard Meyer (Trinity University) argued that even if the new model makes economic sense, people may still want to come to the information to overcome the social isolation created by technology. Noam may also have slighted the economic benefits of resource sharing and the library's role in providing guidance to users to manage the vast quantity of available information. Finally, Ellen Waite (Loyola University) countered that Noam's formulation was too simplistic. She drew upon the models of other futurists to present her ten trends that will in part counterbalance Noam's bleak predictions. $-R o b$ ent P. Holley, Wayne State University

\section{Library investments}

"Listen! Listen! Listen to the distress cries of librarians around North America," Michael Keller began, enumerating myriad familiar problems resulting from downsized staffs and reduced budgets in his presentation, "Capitalizing on the Library Investment." He reviewed in detail how capital investments are routinely made in the physical facilities, collections, staffs, and services of academic libraries (not to mention the personal investments in continuing education and training made by librarians themselves), setting the stage for how those libraries could leverage their sizeable investments.

Keller listed many reasons why academic libraries should consider potential entrepreneurial opportunities. These include returning responsibility for-and control of-scholarly works to university publishers; the potential market of nonacademics competing for access to collections; and raising capital to reinvest in facilities, collections, staffs, and services.

Using Stanford and other academic libraries as examples, Keller suggested a number of strategies by which academic libraries could leverage their considerable investments, such as digitally producing journals and monographs, instituting memberships for corporations and individuals outside the library's primary clientele, and creating virtual libraries.

Post-presentation discussion focused primarily on how digitized information, which continues to increase exponentially, may be archived and indexed-another possible market niche that librarians may wish to consider.-Margaret $R$. Lambert, University of Memphis

\section{Team-based organization as one option}

Many libraries, both large and small, are experimenting with a team-based approach as one way to increase accountability, do more with less, become more customer-oriented, and use human resources to their fullest. As with so many other developments in libraries, this one has been driven in large part by an unprecedented explosion of information and technology. And as organizational structures change, so do ways of measuring productivity. Not only is it important to know how many books we are buying, cataloging, and binding, but whether the things we are buying are indeed ones our customers need.

The library at Indiana University-Purdue University Indianapolis (IUPUI) has used a 
team-based organizational model for the past year. In this panel session, entitled "Change or Be Changed," Vania Goodwin, Robin Crumrin, and Sharon Hay - three librarians from IUPUIdescribed the challenges posed by the new structure and how it has affected such issues as work flow, evaluation, work satisfaction, and accountability. The presentation generated a lively discussion which served to illustrate the multifaceted potential of a team structure as individual organizations try to apply this model to their own unique requirements.-Maija $M$. Lutz, Harward University

\section{Learning strategies for the information age}

"Collaborating with Faculty in Preparing Students for the Asynchronous Classroom" described a learning and teaching model titled Project Vision, tested at six of Penn State's campuses. Kay Harvey, (Penn State, McKeesport Campus) described the program which was originally designed to be totally asynchronous; 20 students on each of the six campuses would be given laptop computers and would electronically access coursework on the Web, anywhere and anytime. Computer-mediated communication such as e-mail and group conferencing as well as interactive video (Picture Tel) would also play a part. Early in the planning stages faculty began to involve librarians when they realized that students would need assistance with research strategies, accessing online clatabases, critical evaluations, etc.

When the project began, the library studies course "Learning Strategies for the Information Age" was paired with a bioethics class, and the library skills were taught using the bioethics course assignments. The five-week synchronous portion of the course was taught with both regular faculty and librarians in the classroom teaching various modules. The learning strategies portion of the course included modules on teamwork, online and remote access to the OPAC and its databases, search strategies, critical thinking skills, evaluation tools, search engines, e-mail, Powerpoint, and interactive video. The final assignment involved student teams writing a paper and creating a Powerpoint presentation together.

Nancy Dewald, (Penn State, Berks Campus) urged librarians to be proactive in aggressively pursing opportunities to collaborate with teaching faculty and technical support personnel in preparing students for the new learning envi- ronment. With students remotely accessing various databases and the Internet, we must help them develop skills in thinking critically about these resources. We need to make faculty aware of the new skills needed in the networked classroom, and we need to discuss curricular innovation and our role in it to campus administrators who can do much to encourage such collaborations.-Debbie Malone, Ursinus College

\section{Collaboration: Teaching faculty and librarians}

In "Collaborating for Information Literacy in Graduate Education via the World Wide Wel)," Katherine Holmes and Cynthia Brown (Lesley College) described their collaboration in creating and presenting a library research workshop for the required graduate course "Educational Research \& Evaluation" taught in a weekend format off campus. Web pages were developed for presentation of the process-oriented workshop intended to prepare students for computerized research. The Web site allows for ongoing student research on and off campus. Holmes and Brown demonstrated one of the active learning techniques they use by involving the audience in a brainstorming exercise to list synonyms for formulating a search. In addition to teaching the necessary electronic research skills, they wish to model collaboration and Internet support of teaching and learning to the students and other faculty on campus.

Holmes and Brown urged librarians to initiate collaboration with teaching faculty, publicize those collaborations on campus, and write about and publish them in journals read by faculty to encourage this kind of work. Holmes also recommended the use of software such as Webwacker when presenting Web materials at a remote site.-Mary Ann Barton, University of Nebraska

\section{No library is an island}

Much is being written about the need for libraries to form partnerships in order to meet the needs of library users. An example of this is a project taking place at ALCOM, the National Science Foundation's Science and Technology Center for Advanced Liquid Crystalline Optical Materials. Laura Bartolo, (Kent State University and ALCOM principal investigator), presented "Building Partnerships: A World Wide Web-based Information Management/Preprint Tool for Research Scientists, Government Researchers, and Industrial Partners in the Phase Separation 
Project." Bartolo's talk focused on one goal of the Phase Separation Project: constructing a Web server to contain scientific information.

To meet the challenge of indexing cross-disciplinary information, the researchers are building a thesaurus using indexing terms from INSPEC, Compendex, and CA which covers the disciplines of physics, chemistry, and mathematics. The Chemical Physics Interdisciplinary Program Home Page is currently not available to the public, but it may be at some time in the future.

The academic partners in this project are ALCOM at Kent State, Case Western Reserve University, and the University of Akron. The NIST Center for Theoretical and Computational Materials Science (CTCMS) is a government partner. The industrial partners are: IBM, dpiS (XEROX), General Motors, and Raychem Corporation.-Pat Viele, Comell University

\section{Restructuring for learning in the 21 st century}

"If we were creating a university today what would it look like?" asked Alan Guskin, chancellor of Antioch University. This noted academic believes that reduced funding, public demand for accountability, and new technologies will force universities to change in the 21 st century. These changes will greatly impact the current structures of higher education.

Ioes this mean there will be huge classes where learning takes place only in a classroom led by faculty? Or will universities transform the teaching/learning environment? Guskin believes the future of learning will require the integration of new technologies and new models of learning. Through this process, students will take primary responsibility for learning.

A panel of librarians responded to Guskin's model. At the University of Washington, the library is "transforming practices" to reshape the library into "collaborative spaces" for student learning, stated Betsy Wilson. Susan Perry described the process of reorganizing library services at Mt. Holyoke College to reduce costs and become more efficient. However,
Kenneth Frazier (University of Wisconsin-Madison) cautioned us "to remember our sense of history and place" in transforming higher education practices for the 21 st century.-Paula Duffy, Montana State University-Billings

\section{Distance learning issues}

Anna Abate (Nova Southeastern University) presented her experiences in conducting an electronic survey of distance education students in "Determining User Needs in Order to Provide Library Services for Distance Education Programs." Abate reported that use of the electronic survey format means many more people can be contacted at less expense; however, it limits the population to those with electronic access. Also, the surveyor needs to do a lot of advance preparation in order to arrange the necessary permission and gain access to mailboxes. Abate used two different instrumentsone about student use of the library and the other about locating information and research material without reference to the library-in attempting to determine students' information skills and their attitudes toward technology. Her results will be available soon.

Carolyn Snyder, Susan Logue, and Barbara Preece (Southern Illinois University) discussed their examination of issues related to distance education and libraries in "Expanding the Role of the Library in Teaching and Learning: Distance Learning Initiatives." In addition to clarifying terminology and describing some programs, they presented the results of an ARL SPEC survey they conducted about the role of libraries in distance education programs. Their

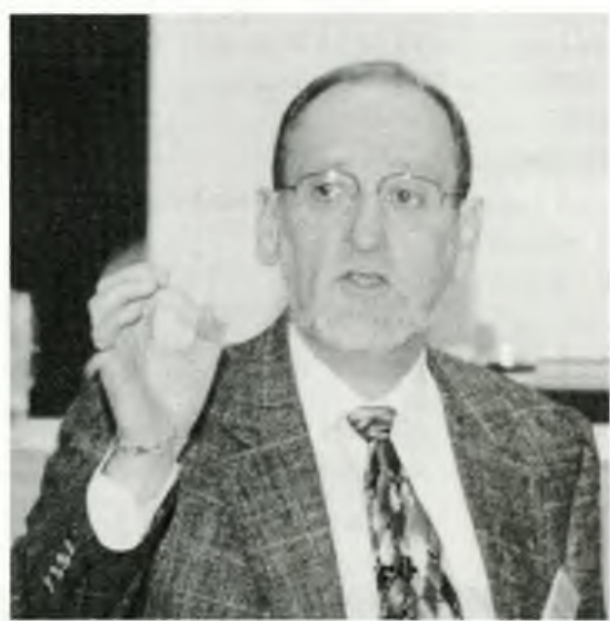

Alan Guskin said universities must adopt new models of learning. results indicate that few libraries are clirectly involved in the administration of clistance education programs. However, most libraries try to provide the same service to remote users as they provide to on-site patrons. The presenters encouraged combining the expertise of teaching faculty, librarians, and instruction technicians to provide good distance learning environments.-Mary Ann Barton, University of $\mathrm{Ne}$ braska 


\section{Your partner in creating innovative solutions for libraries.}

"We created TIPS as an efficient way to manage collection development activities."

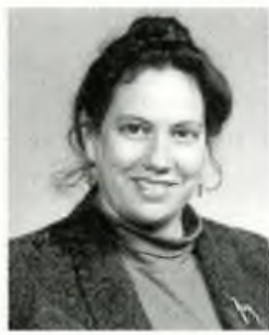

Lauren K. Lee, M.Ln. Manager, Collection Development Services, Brodart Co,

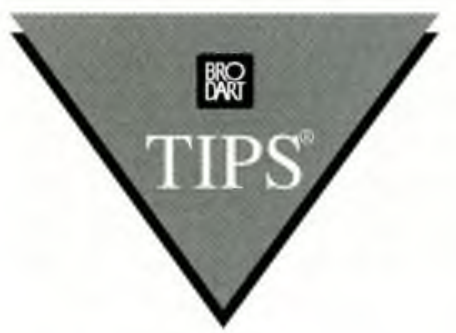

\section{Brodart Co.}

Automation - Books - Furniture - Supplies 500 Arch Street, Williamsport, PA 17705

800-233-8467, Ext. 756. Fax 800-999-6799

Brodart Ltd., 109 Roy Blvd.,

Brantford, Ontario N3R 7K1

Fax 800-363-0483

www,brodart.com

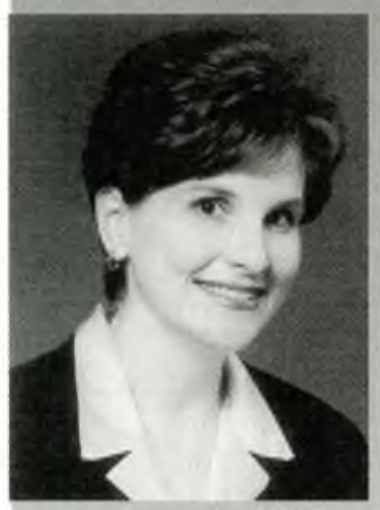

"TIPS helps

organize $m y$ selections, offers timely information, and is a concise avenue for ordering."

Casey McPhee, M.L.S.

Collection Development Coondinator

Pasco County Library System

New Port Richey, Florida

Make your new title selection process easier and more productive with Brodart's TIPS (Title Information Preview Service). Through fifty years of serving the library community, we've learned that saving time is crucial for our library partners.

TIPS:

- consolidates your new title selection activities into one easy process

- gives you the information you need to make the best choices for your specific collection

- eliminates time-consuming searching and keying

Your TIPS selection lists of new and forthcoming titles are designed using your own criteria and can be based on review journak, publishers, series, authors and subjects. TIPS Plus offers full text reviews in several print and electronic formats from:

- Booklist - Kirkus

- Publishers Weekly

- Choice Library Journal School Library Journal

Our experience tells us that you'd rather spend your time selecting titles than searching for them. Combine the experience of Brodart with the expertise of your professional staff.Together, we can construct a plan that will bring your collection development efforts to sure success. 